\title{
Determinants of Economic Growth in East Nusa Tenggara Province
}

\author{
By: \\ Putri Nastiti Wulandari ${ }^{1}$, Lilis Siti Badriah²), Nunik Kadarwati ${ }^{3)}$ \\ ${ }^{1,2,3)}$ Faculty of Economics and Business, Universitas Jenderal Soedirman \\ ${ }^{1)}$ Email: putrimindani@gmail.com
}

\begin{abstract}
This research aims to analyze the determinants of economic growth in East Nusa Tenggara Province, consisting of life expectancy, mean years of schooling, expected years of schooling, purchasing power, labor force participation rate, government investment, and number of tourists on economic growth, and to analyze the dominant variable influencing economic growth. The type of data used in this research is secondary data in the form of panel data with cross sections of 20 regencies/cities and time series for six years (20112016). The analytical tool used is panel data regression with fixed effect model. The results show that life expectancy, mean years of schooling, purchasing power, and government investment have a significant effect on economic growth. Whereas expected years of schooling, labor force participation rate, and number of tourists have no significant effect on economic growth. Life expectancy, mean years of schooling, purchasing power, labor force participation rate, government investment, and number of tourists simultaneously affect economic growth.
\end{abstract}

Keywords: Economic Growth, Human Development Index, Labor Force Participation Rate, Government Investment, Number of Tourists.

\begin{abstract}
ABSTRAK
Penelitian ini bertujuan untuk menganalisis faktor-faktor penentu pertumbuhan ekonomi di Provinsi Nusa Tenggara Timur, yang terdiri dari harapan hidup, rata-rata tahun sekolah, tahun sekolah yang diharapkan, daya beli, tingkat partisipasi angkatan kerja, investasi pemerintah, dan jumlah wisatawan terhadap pertumbuhan ekonomi, dan untuk menganalisis variabel dominan yang mempengaruhi pertumbuhan ekonomi. Jenis data yang digunakan dalam penelitian ini adalah data sekunder berupa data panel dengan cross sections dari 20 kabupaten / kota dan periode selama enam tahun (2011-2016). Alat analisis yang digunakan adalah regresi data panel dengan model fixed effect. Hasil penelitian menunjukkan bahwa harapan hidup, rata-rata tahun sekolah, daya beli, dan investasi pemerintah memiliki pengaruh yang signifikan terhadap pertumbuhan ekonomi. Sedangkan tahun sekolah yang diharapkan, tingkat partisipasi angkatan kerja, dan jumlah wisatawan tidak memiliki pengaruh signifikan terhadap pertumbuhan ekonomi. Harapan hidup, rata-rata tahun sekolah, daya beli, tingkat partisipasi angkatan kerja, investasi pemerintah, dan jumlah wisatawan secara bersamaan mempengaruhi pertumbuhan ekonomi.
\end{abstract}

Kata kunci: Pertumbuhan Ekonomi, Indeks Pembangunan Manusia, Tingkat Partisipasi Angkatan Kerja, Investasi Pemerintah, Jumlah Turis.

\section{INTRODUCTION}

High economic growth is the main target in development because economic growth is a central theme in the Indonesian economy. The ups and downs of a country's development can be seen from economic growth because it is closely related to the increase of goods and services produced in the community. 
The larger the number of goods and services produced, the higher the welfare of society (Soebagyo, 2007).

Economic growth in East Nusa Tenggara, in general, is not much different from the national economic growth. East Nusa Tenggara with the diverse natural resources has the potential to improve the region's economy. The economic performance of East Nusa Tenggara during 2011-2014 tended to decline with an average growth rate of 5.4 percent, lower than the national economic growth rate in the same period of 5.9 percent as shown at Figure 1.

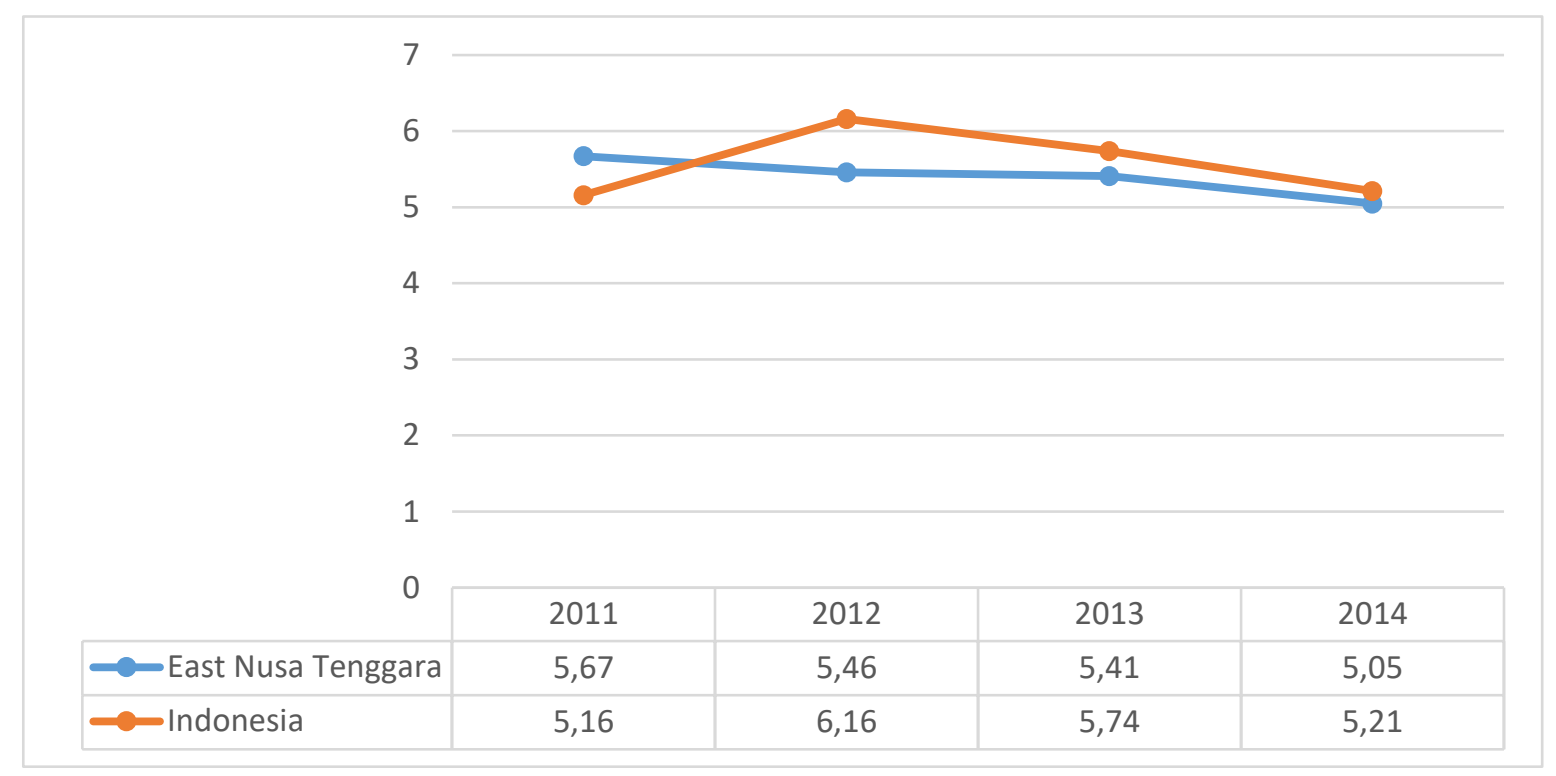

Figure 1. Growth Rate of Gross Domestic Product / Gross Regional Domestic Product Based on Constant Price of 2010

Source: Central Bureau of Statistics of East Nusa Tenggara Province, 2014

Investment is one of the drivers of the economy of a region. The number of realized investments shows an increase in the rate of economic growth, on the contrary, when the realized investment is small it indicates a slow pace of economic growth (Sariningrum, 2010). Capital and labor are two main factors driving the economy of a region or country that turns the input into output in the form of goods and services. Studies conducted by Korua et al. (2016) and Putri (2014) state that Gross Fixed Capital Formation (GFCF) is an important factor in promoting economic development and growth. Therefore, to find out the contribution of GFCF to economic growth, it is necessary to find the relation between quantity and supply of GFCF with the economic growth of a region. The following table presents the distribution of GRDP by expenditure component in East Nusa Tenggara Province.

Table 1. Distribution of GRDP of East Nusa Tenggara Based on Current Price by Expenditure in 20122014 (Percent)

\begin{tabular}{lccc}
\hline Component & 2012 & 2013 & 2014 \\
\hline Household consumption & 78.52 & 77.95 & 75.32 \\
Consumption of non-profit private institutions & 3 & 3.05 & 3.39 \\
Government consumption & 28.48 & 27.52 & 30.69 \\
Gross fixed capital formation & 33.22 & 33.62 & 38.47 \\
Inventory changes & 5.71 & 1.9 & 1.49 \\
Export & 2.24 & 1.95 & 2.01 \\
Import & 1.44 & 1.51 & 1.61 \\
Net export & -49.73 & -44.48 & -49.77 \\
\hline Gross regional domestic product & 100 & 100 & 100 \\
\hline
\end{tabular}

Source: Economic Performance of East Nusa Tenggara, 2014 
Gross fixed capital formation in 2012-2014 has an average contribution of 35.10 percent. In 2012, the gross fixed capital formation in East Nusa Tenggara reached 33.22 percent of the total GRDP of East Nusa Tenggara. The proportion of gross capital formation component for the economy of East Nusa Tenggara in 2013 has increased to 33.62 percent. In 2014, the expenditure component in the formation of GRDP in East Nusa Tenggara increased to 38.47 percent.

The current development paradigm is human development. Human development has a positive influence on economic growth, and conversely, economic growth has a positive influence on human development (Mirza, 2012). UNDP (1991) introduces a measure of human development standards, the so-called Human Development Index (HDI). HDI is used to measure the basic three-dimensional achievements of human development consisting of longevity, knowledge, and decent living standards. $\mathrm{HDI}$ is an important and popular indicator and has been widely adopted by many countries including Indonesia.

Throughout the year 2011-2015 HDI of East Nusa Tenggara Province continued to increase, amounting to 59.21 in 2011 to 62.67 in 2015. Although the HDI of East Nusa Tenggara Province is still lower than the Indonesian HDI, based on the report of the human development index in 2014 from Central Bureau of Statistics (2015), during the period of 2010 to 2014 East Nusa Tenggara recorded as one of the provinces with fastest human development in Indonesia. Based on the report, the regions that have the fastest development of HDI are mostly those that do not have high HDI score. Some regions are those with the lowest HDI. Therefore, low HDI is not an obstacle to increase human development. Regios with low development outcomes have an opportunity to grow faster than those with high performance. East Nusa Tenggara Province succeeded in upgrading human development status from "low" in 2010 to "medium" in 2014.

Ranis (2004) expressed his opinion on the important influence of human development on economic growth. Human development can be regarded as one aspect that can affect the profit maximization. Human development is always associated with human capital, while human capital can affect the economic growth of a region. Table 2 shows the score of human development index for each indicator.

Based on Table 2, the scores of each indicator of the human development index of East Nusa Tenggara are always increasing from 2011 until 2015. The average life expectancy is 66 year, mean years of schooling is 7 year, expected years of schooling is 11 year, and adjusted income per capita is 6,860 million rupiah.

Table 2. The Scores of Human Development Index Indicators of East Nusa Tenggara in 2011-2015

\begin{tabular}{lcccccc}
\hline Indicator Composite & Unit of Measure & 2011 & 2012 & 2013 & 2014 & 2015 \\
\hline Life expectancy & Year & 65.45 & 65.64 & 65.82 & 65.91 & 65.96 \\
Mean years of schooling & Year & 6.6 & 6.71 & 6.76 & 6.85 & 6.93 \\
Expected years of schooling & Year & 10.78 & 10.81 & 11.03 & 11.38 & 11.54 \\
Adjusted real expenditure per capita & Million rupiah & 6,678 & 6,785 & 6,899 & 6,934 & 7,003 \\
\hline
\end{tabular}

Source: Central Bureau of Statistics of East Nusa Tenggara, 2017

Economic growth is influenced by many factors. One of the factors is the labor force participation rate. The magnitude of the role of labor in a region as a driver of the economy can be seen from the Labor Force Participation Rate (LFPR). The growth of regional economy begins by increasing physical capital, creating jobs, increasing production capacity, and improving technology so that welfare can be achieved.

The economic growth in East Nusa Tenggara Province from 2011-2014 as shown in Figure 1 tends to slow down. Table 3 shows that the LFPR in 2011-2015 has increased, but it decreased in 2013. The highest LFPR was observed in 2012. The following table shows the LFPR in East Nusa Tenggara Province. 
Table 3. Labor Force Participation Rate of East Nusa Tenggara Province in 2011-2015

\begin{tabular}{cc}
\hline Year & Labor Force Participation Rate (\%) \\
\hline 2011 & 68.44 \\
2012 & 69.89 \\
2013 & 68.15 \\
2014 & 68.91 \\
2015 & 69.25 \\
\hline
\end{tabular}

Source: Central Bureau of Statistics of East Nusa Tenggara, 2015

In addition to human capital, tourism can also be used as a catalyst in the development of a region or country. Tourism can accelerate income distribution and increase employment, tax revenue and national income. Tourism has an impact on the regional economy. The arrival of foreign and domestic tourists to tourist destinations can provide prosperity for the population where tourism is developed (Yoeti, 2008).

Based on Figure 2, number of domestic tourists to East Nusa Tenggara from 2011-2015 is higher than that of foreign tourists. The number of domestic tourists tends to increase, although there was a decrease in the number of tourists in 2013. The number of foreign tourists has decreased in 2012 and 2013. The decline in the number of foreign tourists is due to extreme weather in Indonesia and other countries (travel.kompas.com).

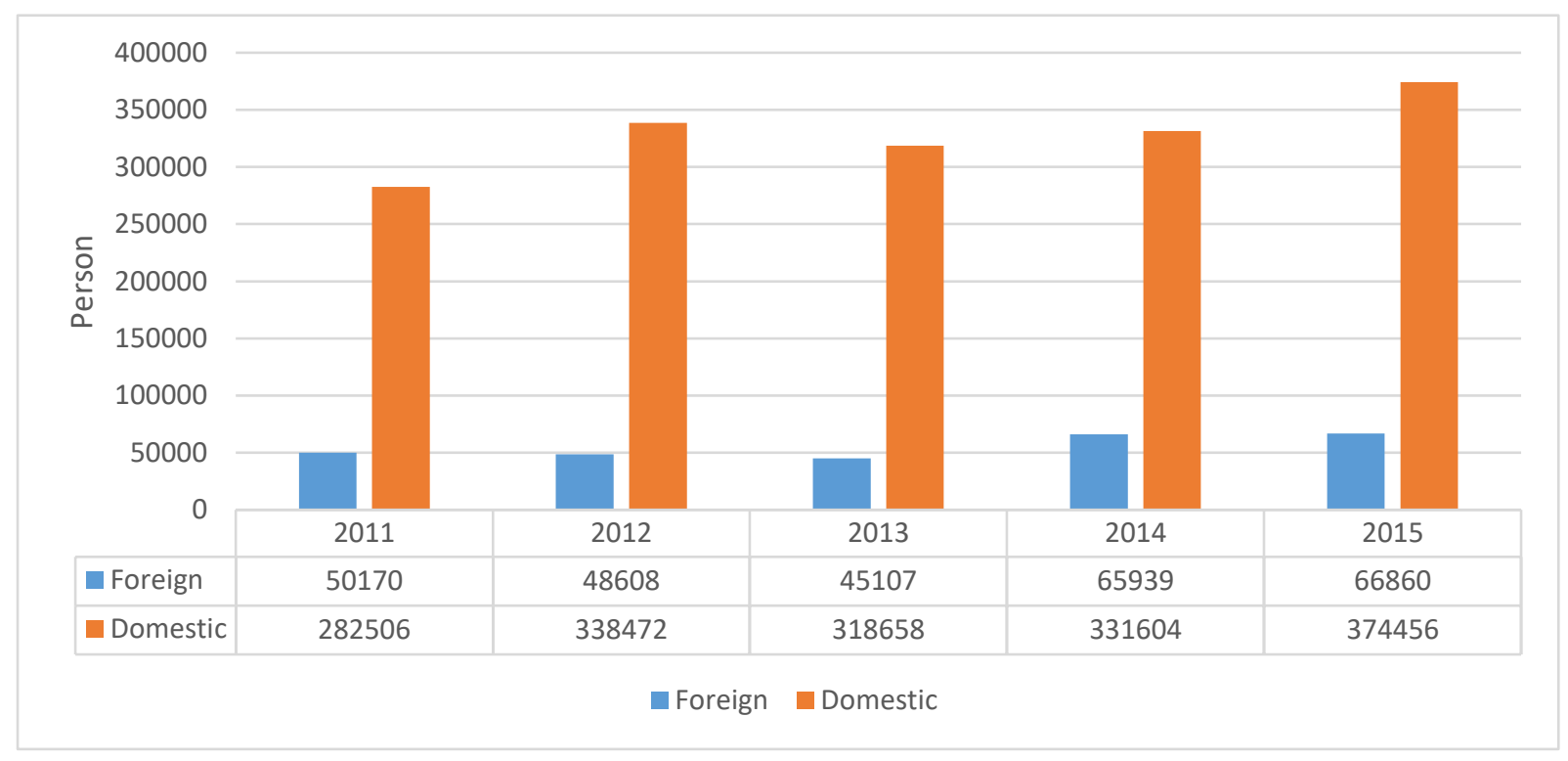

Figure 2. Number of Foreign and Domestic Tourists to East Nusa Tenggara in 2011-2015 Source: Central Bureau of Statistics of East Nusa Tenggara, 2016

The increase of HDI, LFPR, government investment, and number of tourists is not followed by the increase of economic growth of East Nusa Tenggara Province. This study addresses the following research questions:

1. How is the influence of life expectancy, mean years of schooling, expected years of schooling, purchasing power, Labor Force Participation Rate, government investment, and number of tourists on economic growth in East Nusa Tenggara Province?

2. Which independent at variable has the dominant effect on economic growth in East Nusa Tenggara Province?

\section{METHODS}

This study used secondary data obtained from local government agencies using panel data, which is a combination of cross section and time series. Secondary data is obtained from the website of Central 
Bureau of Statistics of West Sumba, East Sumba, Kupang, South Timor Tengah, North Timor Tengah, Belu, Alor, Lembata, East Flores, Sikka, Ende, Ngada, Manggarai, Rote Ndao, West Manggarai, Southwest Sumba, Nagekeo, East Manggarai, Sabu Raijua, and Kupang City from 2011 to 2016. The model used in this research is as follows:

$$
E G=f(L E, M Y S, E Y S, P P, L, G, T)
$$

The equations of panel data regression model can be formulated in the following model:

$$
E G_{i t}=\alpha_{i t}+\beta_{1} L E_{i t}+\beta_{2} M Y S_{i t}+\beta_{3} E Y S_{i t}+\beta_{4} L n P P_{i t}+\beta_{5} L_{i t}+\beta_{6} G_{i t}+\beta_{7} L n T_{i t}+\varepsilon_{i t}
$$

\begin{tabular}{|c|c|}
\hline $\mathrm{EG}_{i t}$ & $=$ Economic growth (percent) \\
\hline$\alpha$ & $=$ Constant \\
\hline i & $=$ Regency/City in East Nusa Tenggara \\
\hline $\mathrm{t}$ & $=$ Time $(2011-2016)$ \\
\hline$\beta$ & $=$ Regression coefficients \\
\hline $\mathrm{LE}_{i t}$ & $=$ Life expectancy (year) \\
\hline MYS $_{i t}$ & $=$ Mean years of schooling (year) \\
\hline $\mathrm{EYS}_{\text {it }}$ & $=$ Expected years of schooling (year) \\
\hline $\operatorname{LnPP}_{i t}$ & $=$ Natural logarithm of purchasing power (percent) \\
\hline $\mathrm{L}_{i t}$ & =Labor Force Participation Rate (percent) \\
\hline $\mathrm{G}_{i t}$ & $=$ Gross Fixed Capital Formation (percent) \\
\hline $\operatorname{LnT}_{i t}$ & $=$ Natural logarithm of number of tourists (percent) \\
\hline$\varepsilon$ & $=$ Standard error \\
\hline
\end{tabular}

Where:

The research used Panel Least Square (PLS) regression with Generalized Least Square (GLS) method to examine the effect of independent variables on the dependent variable. GLS is an estimation method that produces information explicitly and is capable of producing Best Linear Unbiased Estimator/BLUE (Gujarati and Porter, 2013). A standardized coefficient beta test is carried out to determine the independent variable that has a dominant influence on the dependent variable (Ghozali, 2005).

\section{RESULT AND DISCUSSION}

\section{Panel Data Estimation}

After regressing the data by using the EGLS panel method (cross-section weights), conducting the Chow test and Hausman test, the model that should be used to analyze panel data is the fixed effect model.

Table 4. The Result of Panel Data Regression Using Fixed Effect Model

\begin{tabular}{lcccc}
\hline Variable & Coefficient & Std. Error & t-Statistic & Prob. \\
\hline C & -2.885296 & 13.70721 & -0.210495 & 0.8337 \\
LE & -0.325979 & 0.116859 & -2.789494 & 0.0064 \\
MYS & 0.246509 & 0.119726 & 2.058944 & 0.0423 \\
EYS & -0.078617 & 0.075532 & -1.040831 & 0.3007 \\
LNPP & 3.356393 & 1.501946 & 2.234697 & 0.0278 \\
L & -0.000685 & 0.003451 & -0.198450 & 0.8431 \\
G & -0.027906 & 0.011228 & -2.485445 & 0.0147 \\
LNT & -0.045440 & 0.030014 & -1.513989 & 0.1334 \\
Adjusted R & 0.798910 & & & \\
F-Statistic & 19.18363 & & & \\
\hline
\end{tabular}


Based on Table 4, the equation model of regression by using the fixed effect model is:

$$
\begin{gathered}
E G_{i t}=-2.89_{i t}-0.33 L E_{i t}+0.25 M Y S_{i t}-0.08 E Y S_{i t}+3.36 L n P P_{i t}-0.00 L_{i t}-0.03 \beta_{6} G_{i t} \\
-0.05 L n T_{i t}+\varepsilon_{i t}
\end{gathered}
$$

\section{Classical Assumption Test}

\section{Autocorrelation Test}

Based on the results of panel data regression analysis, the value of $d$ is 1.5574 with $n=120,7$ independent variables, and $\alpha 0.05$. The value of $d$ is in the positive area of autocorrelation $(1.5574 \leq$ 1.5628) meaning that the combination of variables has autocorrelation problems. Nevertheless, the model equation can still be used. EGLS panel data estimation method (cross-section weights) can tolerate the existence of every problem in the classical assumption test because it has been transformed by minimizing the number of residual squares to produce BLUE (Gujarati and Porter, 2013).

\section{Multicollinearity Test}

Based on Table 5, it can be seen that the independent variables used in the panel data estimation model do not have multicollinearity problems because the correlation coefficient between independent variables is less than 0.8 .

Table 5. Results of Multicollinearity Test

\begin{tabular}{lccccccc}
\hline & LE & MYS & EYS & LnPP & L & G & LnT \\
\hline LE & 1.000000 & 0.374509 & 0.158142 & 0.390830 & -0.081804 & -0.103816 & 0.316953 \\
MYS & 0.374509 & 1.000000 & 0.615518 & 0.793545 & -0.340366 & 0.463708 & 0.452475 \\
EYS & 0.158142 & 0.615518 & 1.000000 & 0.566041 & -0.385462 & 0.389105 & 0.144067 \\
LnPP & 0.390830 & 0.793545 & 0.566042 & 1.000000 & -0.391128 & 0.374149 & 0.526308 \\
L & -0.081804 & -0.340366 & -0.385462 & -0.391128 & 1.000000 & -0.199174 & -0.186938 \\
G & -0.103816 & 0.463708 & 0.389105 & 0.374149 & -0.199174 & 1.000000 & 0.431052 \\
LnT & 0.316953 & 0.452475 & 0.144068 & 0.526308 & -0.186938 & 0.431052 & 1.000000 \\
\hline
\end{tabular}

Source: Eviews 9.0 Output, 2018

\section{Heteroscedasticity Test}

Based on Table 6, the probability Obs * R-squared is less than 0.05 . It means the equation in this model experiences heteroscedasticity. Nevertheless, EGLS panel data estimation method (cross-section weights) can tolerate the problem of autocorrelation and heteroscedasticity in the classical assumption test because it has been transformed by minimizing the number of residual squares to produce BLUE (Gujarati and Porter, 2013).

Table 6. Results of Heteroscedasticity Test (Glejser)

\begin{tabular}{llll}
\hline F-statistic & 6.703391 & Prob. F $(7,112)$ & 0.0000 \\
\hline Obs*R-squared & 35.43113 & Prob. Chi-Square (7) & 0.0000 \\
Scaled explained SS & 48.36769 & Prob. Chi-Square (7) & 0.0000 \\
\hline
\end{tabular}

Source: Eviews 9.0 Output, 2018

\section{Coefficient of Determination (Adjusted $\mathbf{R}^{2}$ )}

The coefficient of determination is used to measure the extent to which the model is capable of explaining the dependent variable. Based on the estimation results, adjusted $R^{2}$ is 0.79 . It means that the variation of independent variables from life expectancy, mean years of schooling, expected years of schooling, purchasing power, labor force participation rate, government investment, and the number of tourists can explain 79 percent of variation of the dependent variable and 21 percent is explained by other variables that are not included in this study. 


\section{Simultaneous Test (F-Test)}

The $\mathrm{F}$ test is used to show whether the independent variables have a simultaneous effect on the dependent variable by using a level of significance of 5 percent. Testing is done by comparing the Fstatistic values with F-table. When F-statistic is greater than F-table, the independent variables have a significant effect on the dependent variable. The following table shows the result of simultaneous test estimate.

Table 7. Results of Simultaneous Test (F-Test)

\begin{tabular}{lc}
\hline F-statistic & 19.18363 \\
F(F-statistic) & 0.000000 \\
F-table & 2.09 \\
\hline
\end{tabular}

Source: Eviews 9.0 Output, 2018

Table 7 shows that the F-statistic value is 19.18363 with $n=120, k=8, \alpha=0.05$, $\mathrm{df}$ for the numerator $(k-1=7)$, and df for the denominator $(n-k=113)$; then the F-table value obtained is 2.18. Fstatistics (19.18) > F-table (2.09) means that all independent variables have a significant effect on the dependent variable.

\section{Individual Parameter Test (t-Test)}

The t-test is used to determine whether each independent variable has a significant influence on the dependent variable. The following table shows the result of the t-test.

Table 8. Results of Individual Parameter Test (t-Test)

\begin{tabular}{lccc}
\hline Variable & t-Statistic & t-table & Prob. \\
\hline LE & -2.789494 & 1.98137 & 0.0064 \\
MYS & 2.058944 & 1.98137 & 0.0423 \\
EYS & -1.040831 & 1.98137 & 0.3007 \\
LNPP & 2.234697 & 1.98137 & 0.0278 \\
L & -0.198450 & 1.98137 & 0.8431 \\
G & -2.485445 & 1.98137 & 0.0147 \\
LNT & -1.513989 & 1.98137 & 0.1334 \\
\hline
\end{tabular}

Source: Eviews 9.0 Output, 2018

Based on the result of estimation in Table 8, life expectancy, mean years of schooling, purchasing power, and government investment have a significant effect on economic growth of East Nusa Tenggara Province, whereas expected years of schooling, LFPR, and number of tourists do not have a significant effect.

\section{Life Expectancy}

The results showed that life expectancy (LE) had a significant negative effect on the economic growth of East Nusa Tenggara Province. The coefficient of life expectancy is -0.33 , this means that if life expectancy rises by one year, it can reduce the economic growth of East Nusa Tenggara Province by 0.33 percent. The average of LE of the population of East Nusa Tenggara is 66 years, and the majority of the population (an average of 61 percent) of East Nusa Tenggara Province works in the primary sector. This sector has the biggest contribution to the GDRP of East Nusa Tenggara although its growth tends to decline during 2011-2016. The decline in primary sector growth indicates a decline in productivity. Because this sector contributed the most to the economic growth of East Nusa Tenggara, the decline in this sector also affected the economic growth.

The results of this study are not in line with the research hypothesis and research conducted by Lorentzen et al. (2008) and Aghionet al. (2012) which shows that health has a positive impact on economic growth through increased worker productivity. The results of this study are in line with the 
research of Acemoglu and Johnson (2007) and Barro and Lee's research (2010) which did not find a positive relationship between life expectancy at birth and economic growth.

\section{Mean Years of Schooling}

The result shows that the mean years of schooling had a significant positive effect on the economic growth of East Nusa Tenggara Province. The mean years of schooling coefficient of 0.24 means that when there is a year increase in the mean years of schooling, the economic growth of East Nusa Tenggara Province will increase by 0.24 percent. Therefore, the hypothesis is supported. This result also supports the previous findings by Dewi and Sutrisna (2014) and Rahatanti (2014).

\section{Expected Years of Schooling}

The results of the study show that the expected years of schooling does not have a significant effect on the economic growth of East Nusa Tenggara Province. The average number of expected years of schooling taken by the population of East Nusa Tenggara is 12 years, which means that the average population aged seven years who enter formal education has the opportunity to attend school for 12 years or equivalent of senior high school (BPS, 2016). However, higher expected years of schooling does not necessarily lead to higher economic growth. This could be due to the fact that there should be link and match between education and empoyment. When the education does not produce the skills needed by employers, the workforce absorption remains low.

The results of this study are not in line with the research hypothesis which states that the expected years of schooling have a positive and significant effect on economic growth in East Nusa Tenggara Province. Also, they are not in line with Mankiw (2003) which states that a country that gives a lot of attention for example in the form of policies in the field education and subsidies in the form of scholarships will produce better economic growth than those who do not. This is also not in line with studies conducted by Schultz, Harbison, Dension, Kendrick, Moses Abramovitz, Becker, Mary Bowman, Kuznets, and a group of economist others stated that one of the several important factors that led to the rapid growth of the American economy was education financing which was relatively always increasing. Studies show that the dollar invested in education brings a more significant increase in national income. Without developing education, knowledge, and skills, productivity will decline (Jhingan, 2013).

\section{Purchasing Power}

The result of the study shows that purchasing power has a positive and significant effect on the economic growth of East Nusa Tenggara Province. The regression coefficient of purchasing power of 3.36 means that one percent increase in purchasing power will increase the economic growth of East Nusa Tenggara Province by 3.36 percent. The research hypothesis is supported, and it also supported the research by Nurmainah (2013) and Dewi and Sutrisna (2014) that expenditure per capita has a significant positive effect on economic growth.

\section{Labor Force Participation Rate}

The result shows that the labor force participation rate had no significant effect on the economic growth of East Nusa Tenggara Province. The workforce absorbed in the Province of East Nusa Tenggara tends to decline with an average of 1.61 percent throughout 2011-2016. The number of people who work is dominated by the population of elementary school graduates. The level of workers' education affects their productivity; the higher the education level, the higher the productivity. This may lead to the insignificant effect of labor force participation rate on economic growth. Therefore, the hypothesis is not supported.

The result of this study is not in line with the classical and neoclassical growth theory which states that labor has a positive effect on economic growth. According to neo-classical growth theory, output growth always comes from one or all of three factors. They are the increase in the quality and quantity of labor, the addition of capital (savings and investment), and the improvement of technology (Todaro 
and Smith, 2011). This result research does not confirm Maharani and Isnowati (2014), Raleva (2014), and Jajri and Ismail (2010) who indicate that labor has a positive and significant effect on economic growth.

\section{Government Investment}

The result of the study shows that government investment has a negative and significant effect on the Economic Growth of East Nusa Tenggara Province. The government investment coefficient is -0.03 , it means if there is a one percent increase in government investment will reduce the economic growth of East Nusa Tenggara Province by 0.03 percent.

The negative influence of government investment on economic growth is due to the long-term impact of the investment. This influence is supported by the Harrod-Domar theory which states that investment influences both long-term demand and supply. It will cause an increase in capital stock such as roads, factories, and others. The GFCF component is related to the existence of fixed assets involved in the production process. The time span in this study is five years, during which the increase in government investment has not been able to increase the economic growth of East Nusa Tenggara. Furthermore, the investment in East Nusa Tenggara is not supported by the capability of workers. The employment is dominated by elementary school graduates so that they have not been able to optimally utilize available investments, their productivity is low and ultimately lead to inefficiency. The results of this study support the finding of Ramayani (2013).

\section{Number of Tourists}

Number of tourists does not have a significant effect on the economic growth of East Nusa Tenggara Province. Tourism in East Nusa Tenggara is a potential sector, but this is not widely well known to tourists, so the number of tourist visits is still relatively small. This condition could be in part due to the lack of tourism promotion in the province.

The results of this study are not in line with the research hypothesis and the finding of by Amnar, et al. (2017), which concludes that number of tourist visits has a significant positive effect on regional economic growth in Sabang City and Ahad (2016) who find that number of tourist visits has a positive impact on economic growth in Pakistan.

\section{The Variable that Has a Dominant Influence on the Economic Growth of East Nusa Tenggara Province}

Based on the results of panel data regression, it is known that the independent variable that has the dominant influence on economic growth in East Nusa Tenggara Province is the purchasing power because it has a greater coefficient value than the other independent variables.

This result is in line with the research hypothesis and Sukirno (2013) which states that consumption is directly proportional to the income. Household decisions affect the overall long-term and short-term economic behavior. Household expenditure on consumption has an impact in determining the fluctuation of economic activity. Variations in consumption are essential elements that show that changes in consumer spending plans could affect the economy. This result supports the research conducted by Mahrany (2012) and Kim (2017) which stated that expenditure per capita has a significant influence on economic growth.

\section{CONCLUSION}

Life expectancy (LE) and government investment have a significant negative effect on economic growth in East Nusa Tenggara Province. Mean years of schooling (MYS) and purchasing power have a significant positive impact on economic growth in East Nusa Tenggara Province. Expected years of schooling (EYS), labor force participation rate (LFPR), and number of tourists have no significant effect on economic growth in East Nusa Tenggara Province. The independent variable that has the dominant influence on the economic growth in East Nusa Tenggara Province is purchasing power because it has the highest coefficient value than other independent variables. 
The government needs to concern the issues related to factors that influence economic growth, especially for the human development index in the education component so that it can be further improved. This effort will improve the quality of human resources in East Nusa Tenggara Province, which in turn will increase their productivity and thus economic growth. Investment in the real sector in the form of credit for Small Medium Enterprises (SMEs) can be promoted so that SMEs can develop their businesses, and in the future, it can increase production and absorb new workers and increase workers' income which in turn encourages economic growth. Furthermore, the provision of subsidies for production factors such as machinery and other supporting production equipment can provide convenience for entrepreneurs, especially small entrepreneurs who have just started their businesses. Employment should be promoted, especially in the secondary and tertiary sector. The more intensified marketing in the tourism sector needs to be encouraged in order to promote the diversity of regional tourism through the mass media as well as social media.

The limitation of this research is that it covers only 2011-2016 period with 20 regencies/cities in East Nusa Tenggara Province due to missing data. Further research should examine all regencies and other independent variables that are not included in this study.

\section{REFERENCES}

Acemoglu, D. \& Johnson, S. (2007). Disease and development: the effect of life expectancy on economic growth. Journal of Political Economy, 115(6), 925-985.

Ahad, M. (2016). Does tourism-led growth hypothesis exist in Pakistan?: a fresh look from combine cointegration and causality approach with structural breaks. International Journal of Economics and Empirical Research, 4(2), 94-111.

Aghion, P., Howitt, P., \& Murtin, F. (2012). The relationship between health and growth: when Lucas meets Nelson-Phelps. Journal of Economics and Institutions, 2(1), 1-24.

Amnar, S., Muhammad, S., \& Syechalad, M. (2017). The Effect of tourism on economic growth in the City of Sabang. Indonesian Economic and Public Policy Journal, 4(1), 13-22.

Central Bureau of Statistics. (2015). 2014 human development index. Jakarta, Indonesia: Central Bureau of Statistics. . (2015). East Nusa Tenggara in figures. East Nusa Tenggara, Indonesia: Central Bureau of Statistics.

. (2016). East Nusa Tenggara in figures. East Nusa Tenggara, Indonesia: Central Bureau of Statistics.

. (2017). East Nusa Tenggara in figures. East Nusa Tenggara, Indonesia: Central Bureau of Statistics.

Dewi, N. I. S. \& Sutrisna, I. K. (2014). Effect of components of the human development index on the economic growth of Bali Province. EP Unud E-Journal, 3(3), 106-114.

Barro, R. J. \& Lee, J. W. (2010). A new data set of educational attainment in the world, 1950-2010. NBER Working Paper No. 15902, April 2010, 1-47.

Jhingan, M. L. (2013). The economics of development and planning (translated by Guritno). Jakarta, Indonesia: Rajawali Press.

Lorentzen, P., Mcmillan, J., \& Wacziarg, P. (2008). Death and development. Journal of Economic Growth, 13(2), 81-124.

Maharani, K. \& Isnowati, S. (2014). Study of investment, government expenditures, labor, and economic openness on economic growth in Central Java Province. Journal of Business and Economics, 21(1), 62-72. 
Mahrany, Y. (2012). Effect of composite indicators on human development index on economic growth in South Sulawesi. Business-Economics, 6(1), 89-106.

Mankiw, N. G. (2003). Macroeconomic theory (translated). Jakarta, Indonesia: PT. Gramedia Pustaka Utama.

Mirza, D. S. (2012). The effect of poverty, economic growth, and capital expenditure on the human development index in Central Java in 2006-2009. Economics Development Analysis Journal, 1(2), 1-15.

Nurmainah, S. (2013). Analysis of the effect of government capital expenditures, absorbed labor, and human development index on economic growth and poverty: case study of 35 districts / cities in Central Java Province. Journal of Business and Economics, 20(2), 131-141.

Ghozali, I. (2005). Application of multivariate analysis with SPSS. Semarang, Indonesia: Diponegoro University Publishing Agency.

Gujarati, D. N. \& Porter, D. C. (2013). Basic Econometrics (fifth edition) (translated by Eugenia Mardanugraha, Sita Wardhani, \& Carlos Mangunsong). Jakarta, Indonesia: Salemba Empat.

Jajri, I. \& Ismail R. (2010). Impact of labor quality on labor productivity and economic growth. African Journal of Business Management, 4(4), 486-495.

Kim, H. (2017). The effect of consumption on economic growth in Asia. Journal of Global Economics, $5(3), 1-8$.

Putri, P. I. (2014). The effect of investment, labor, capital expenditures, and infrastructure on the economic growth of Java. JEJAK Journal of Economics and Policy, 7(2), 109-120.

Rahatanti, O. (2014). Effect of human capital, physical investment, and number of workers on economic growth in East Java Province in 2004-2011. Economic Journal, 4(3), 202-215.

Ramayani, C. (2013). Effect of government investment, private investment, inflation, exports, labor, and productivity of workers on economic growth in Indonesia. ECONOMICA Journal of Economic and Economic Education, 1(2), 203-207.

Ranis, G. (2004). Human development and economic growth. Center Discussion Paper No. 887, Yale University: Economic Growth Center, 1-13.

Raleva, S. (2014). Impact of labor on economic growth in Bulgaria (1991-2013). Economic Alternatives, 3, 5-14.

Korua, F. S., Vekie, A. R., \& Siwu, H. F. D. (2016). The effect of government investment on economic growth through labor as variable intervening in North Sulawesi Province 2003-2013. Efficiency Scientific Periodic Journal, 16(1), 410-417.

Soebagyo, D. (2007). Granger causality of GRDP on job opportunities in Central Java Province. Journal of Development Economics, 8(2), 177-192.

Sariningrum, A. (2010). Analysis of the effects of investment, labor, and exports on Indonesia's gross domestic product (GDP) in 1990-2007. Journal of Development Economics, 2(3), 45-69.

Sukirno, S. (2013). Modern Macroeconomics. Jakarta, Indonesia: PT. Raja Grafindo Persada Publisher.

Todaro, M. P. \& Smith, S. C. (2011). Economic development (eleventh edition). United States: Addison Wesley.

Yoeti, O. (2008). Tourism economics: introduction, information, and implementation. Jakarta, Indonesia: Kompas Publisher.

UNDP. (1991). Human development report. New York: Oxford University Press. Retrieved from http://hdr.undp.org. Accessed on April $22^{\text {nd }}, 2018$. 